\title{
PERFORMANCE INVESTIGATION OF ELECTRICIAL POWER SUPPLY TO OWERRI FOR HIGHER PRODUCTIVITY
}

\author{
Osueke G. O' , Emeka-Opara F. O $^{2}$ \\ ${ }^{1}$ Dept. of Mechanical Eng, Federal University of Tech, Owerri, Nigeria \\ ${ }^{2}$ National Productivity Centre, Abuja. Nigeria
}

\begin{abstract}
This research was carried out to investigate the performance of electrical power supply to Owerri, Imo State Capital. The Enugu Electrical Distribution Company (EEDC), Owerri was the case study and sample of 10 respondents representing each unit were used. Structured questionnaire and observations techniques were administered during this research. The data presentation tools were tables and charts. It was found out that the major hindrances to Customer satisfaction in Power supply were: inadequate megawatts of power availability, obsolete network and equipment that require upgrade, overload networks, poor funding, lack of routine maintenance culture, inadequately trained manpower, logistics (vehicle, personal and material problems), psychological and physiological problems. Although the privatization policy is believed to be a progressive step to these challenges. based on the aforementioned, it was therefore recommended that management's proactiveness to manage faults and equipment upgrade, government and private sectors should actively involve positive and effective management, as well as smart metering to ensure consumers meet up with charges, Standard Organization of Nigeria (SON) play major to ensure substandard materials and products are not delivered, form rural cooperative society to create awareness on how to use light and serve as interface between the company and community.
\end{abstract}

Keywords: Performance, Electric Power, Investigation, Supply, Productivity.

\section{INTRODUCTION}

There has been a general and widespread agitation by the Owerri populace and the country at large for efficient performance by public corporations most especially those of them that have direct and equally noticeable impact on their lives like the National Electric Power Authority, (NEPA), Chen (2007). It is unfortunate to note that NEPA has ended up accumulating a huge amount of debt apparently so huge that it could not manage effectively.

It is obviously a prevailing social and economic problem when considering the incessant power outages in relation to the nation's endowment with natural resources like crude oil, natural gas , large amount of other hydrocarbon resources. The under-utilization of these resources, complaints and poor management polices has affected the performance, reliability, and even economic productivity of this sub-sector. The public (electric consumers) allegedly has claim of extortion and exploitation by providers of electricity in owerri, Echeta (2012). This has adversely posed many losses and retarded the economic growth and development.

Against the above background, there came the need to investigate the incidences of power outage, load shading and epileptic power supply as well the performance of the electricity supply within Owerri after post privatization policy by the Federal Government in 2013, aimed at (i) increased access to electricity services; (ii) improved efficiency, affordability, reliability and quality of services; and (iii) greater investment into the sector, to stimulate Productivity growth.

\subsection{Statement of Problem}

Following the incidences of low performance, poor quality service delivery, power outage, load shading and epileptic power supply that bedevil the power sector with the increasing consumption and population rate, Echeta (2012) maintained that Power supply has fallen below the demand in Owerri.

\subsection{Electricity Generation Company till the Privatisation (Birth of EEDC).}

According to national-electricpowerauthority.blogspot.com, Nigeria's Public Electricity Generating company, National Electric Power Authority (NEPA) was created by government Decree No. 24 of 1972. That Decree gave NEPA the mandate to "maintain, co-ordinate an efficient and economic system of electricity supply to all parts of the country".

However, from year 2005, it ceased to exist and has now been renamed Power Holding Company of Nigeria, PHCN, with 18 business units. The country of about 160 million people, has a total installed power generating capacity of 4,000 MW, derived from both hydro and thermal power plants. But actual power generation is often much less, typically between 1,500 to $2,500 \mathrm{MW}$, current actual output in a mere $1,400 \mathrm{MW}$, at least, 1,000 MW short of the actual demand in the country put at 2,400 MW. The Authority 
generates electricity through two major sources: Hydro and Thermal. The Hydro Power stations are Kainji Hydro Power station with capacity of 760MW, Jebba Hydro Power station with 578.4MW capacity, Shiroro Hydro Power Station 600MW. The Thermal Power stations are: Afam Thermal Power station with 696MW, Lagos thermal power station, Delta IV thermal Power station with 600MW and Sapele Thermal Power station 1020MW.

However, the need to reform the Electricity industry necessitated the transformation of NEPA into Power Holding Company of Nigeria (PHCN) in 2005. The Electricity Reform Act of 2005, unbundled PHCN into 11 Distribution companies, 1 Transmission Company and 6 Generation companies. This Reform Act gave birth to Enugu Electricity Distribution Company (EEDC). According to Osueke (2013), sustainable electric power supply is the prime mover of technological and social development

\section{METHODOLOGY}

The instruments used in this research include i. development and administration of Questionnaire, 2. Literature reviews, 3. Oral interviews, 4. Data analysis and report writing. Data were collected through the administration and retrieval of the questionnaire, as summarized in the analysis.

\subsection{Results, Analysis and Discussions}

Table 1 EEDC Power supply /day.

\begin{tabular}{|l|l|l|}
\hline Hours Supplied. & $\begin{array}{l}\text { No. } \\
\text { Respondents. }\end{array}$ & Percentage \\
\hline $0-2$ & 3 & 17 \\
\hline $3-8$ & 10 & 55 \\
\hline $9-14$ & 5 & 27 \\
\hline $15-$ above & Nil & Nil \\
\hline Total & 18 & 100 \\
\hline
\end{tabular}

In terms of power supply, average services rendered range from $29 \%$ to $46 \%$. The remaining hours of the day is being covered by use of private generators.

For the Owerri Capital Territory; Average Min Supplies = $\frac{7}{24} \times \frac{100}{1}=29 \%$ Across

The Max hrs of supply for Owerri, $=\frac{11}{24} \times \frac{100}{1}=46 \%$ of needed power supply.

$$
\text { Productivity, } \mathrm{P}=\mathrm{F} / \mathrm{C} ;=\frac{i-x}{i}
$$

Where $\mathrm{i}=$ input hours; and $\mathrm{x}=$ waste or unsupplied power. This is supported by productivity and waste equation as shown below:

Productivity,

$$
\mathrm{P}=\frac{\text { OUTPUT }}{I N P U T}=\frac{I N P U T-W A S T E}{I N P U T}=\frac{i-X}{i}, A S X \Rightarrow 0
$$

The challenges encountered during transmission are due to technical hitches such as flux leakage, eddy current loses. Heat losses are also common threat encountered during transmission. The Owerri transmission unit is on regular transmission line inspection by its technical crew. The installation of more transformers will create better chances of effective power transmission Obiajulu (2012). The private establishment plays good role in stabilization of power in Owerri. The consumers attitude in meeting up with service charge on power is fair. The people's reaction to privatization of electricity transmission is at $40 \%-60 \%$ rate. About 85 megawatts of power is transmitted daily to Owerri and is much below the quantity demanded.

The power consumers are billed even when there is no supply because of no meter and fixed charge placed. From above finding and results, the research team were able to create a statistical analysis and results represented on a bar chart below in figure 1:

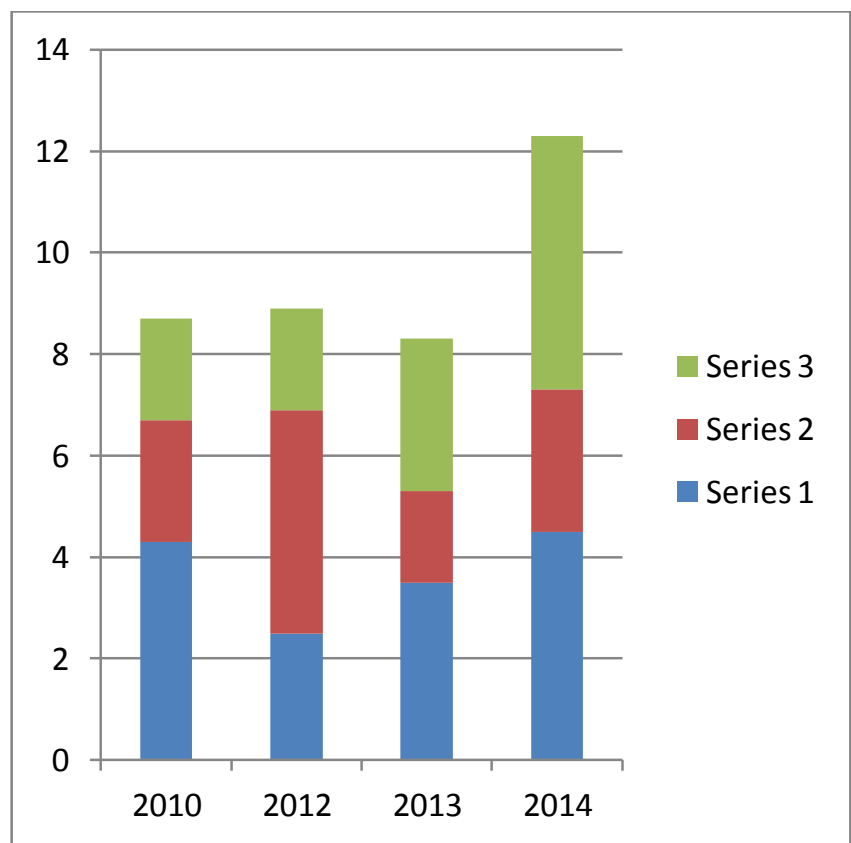

Fig. 1 Bar chart showing performance rate in Owerri

From the bar chart in figure 1, it can been seen that performance of electric power supply has increased in the year 2014, Enugu Electricity Distribution Company has indeed boosted power supply in Owerri. Ever since it was privatized, there has been technical hitches over the last 3 years which are yet to be addressed because of lack of funds and man-power development . Recently, 330KVA line transmission high tension yard was installed in locations like Egbu transmission unit which has boasted power transmission in that part of owerri. Also in the Federal University Of Technology Owerri, two 350kva transformers with armored cable and transmission lines were mounted in the university and ever since then electric power supply has improved .

Presently, in Nigeria electrical power system is facing a lot of challenges as a whole. From generation to distribution, the reliability of the system is far below expectation 
(Popoola, 2011). Recently, the Nigeria government announced the decision to embark on measures to promote the use of energy saving bulbs and meters, as part of solution to the energy crisis. Providing sustainable, adequate , reliable and efficient electricity supply to residential, commercial and industrial consumers is germane to national development .

Results shows that ever since the privatization of PHCN, it has attracted foreign investors to Nigeria and to the case study ,Owerri, network has been upgraded in some sub stations. This policy has affected the society because some workers were laid off and this has posed a security risk to the government, adding to the unemployment level. From findings also, the Distribution manager EDDC carefully stated that more workers in the region were also laid-off.

The research apparently concluded that it is a major disadvantage of the privatization in the country. Notwithstanding, Technology has also been upgraded, computers with internet facilities provided and staff ready and dedicated to work.

This has increased the distribution of power supply in Owerri, management dedication has also seen a change in EDDC which is the bedrock of effective power performance. This is because without good management there cannot be improved productivity.

Results gathered have also shown that the suppliers of materials to EDDC supplied inferior and substandard materials that prompted the low level of performance but management is on high gear to cub further occurrence. Many transmission line fail not because of technical hitches but of failure of material in transmission line and stations However, the company has taken extra measures in increasing supply and material inspection taken a full step. If this is done continuously, result will show that performance of electric power supply will improve effectively.

\section{CONCLUSION}

The results obtained show that the earlier disappointing trend in Electric power supply to Owerri has taken an improvement turnaround, by virtue of services rendered by the EEDC. It is hoped that there will be improved performance in transmission and distribution of power supply in Owerri, if the above mentioned challenges, hindrances and recommendation are efficiently followed up with the privatization policy objectives.

\section{REFERENCES}

[1] Ayodele, A. Sesan (2011). Improving And Sustaining Power (Electricity) Supply

[2] Chen, Kuo (2007) in Echeta, D. O., Okpara, G.I., \& Emerenini, F.M. (2012). Household Demand For Electricity In Owerri Metropolis ;Estimating The Alternative Supply
[3] Comparing and cost of PHCN billing www.naijatechguide.com

[4] Echeta, D. O., Okpara, G.I., \& Emerenini, F.M. (2012). Household Demand For Electricity In Owerri Metropolis ;Estimating The Alternative Supply.

[5] Electricity Regulatory Authority (ERA) (2006), Annual Journal. History of NEPA http://nationalelectricpowerauthority.blogspot.com/2 006/10/history.html

[6] Nweke N.U (2011). Research Methodology: survey method. pp169.

[7] Nigeria Electricity Privatisation Project http://www.nigeriaelectricityprivatisation.com/?page _id=2 Nigeria Electricity Privatisation (PHCN). Retrieved 20/5/14

[8] Nweke, Njideka Uchechukwu (2011). A study of the use of public relations in power Holding company of nigeria (PHCN),Awka. Nnamdi Azikiwe University Awka,

[9] Obiajulul Emejuju, Dan Chima A., Queen Njemanze \& Ijeoma Odoh et al (2012). The dynamics of technical writing and communication .Ibadan. Owerri. Abuja Afrika-link Books

[10] Osueke, G. O. Nwosuh, E. N. and Adenugba, A. (2013). Performance evaluation of quality of service offered by Power Holding Company of Nigeria(PHCN) to coldrooms in Anambra state for higher productivity. 